\title{
Henriett Rab*: \\ The role of the constitutional protection of social rights in the framework of the changing labour market ${ }^{1}$
}

\section{Introduction}

In the world of employment several instances can be observed that have an impact on the status of labour market. On the other hand, labour market is undetectable from the legal regulations of employment; moreover the tendencies and processes on the labour market also determine the role of labour law. In research projects of labour law this interaction is examined from various points of view. There is a significant divergence in the approaches of researchers with roots in the Anglo-Saxon or continental legal systems. In countries with common law system the role of primary law is secondary, while in continental legal systems it is the bulwark of legal protection, thus exclusively law is attributed with the role of warranty. From this point of view, the Anglo-Saxon professional approach is less comprehensible for the continental mind, as it looks too liberal to abandon a mandatory level of regulation and acknowledge a system that - although protected by guarantees of fundamental rights - is regulated by the subjects of labour market and is based on the freedom of decision-making of the parties.

Basically, the Anglo-Saxon legal mind differs in the approach to labour law, direct labour market regulations and to the set of legal guarantees designed to describe and protect employment. From the labour market aspect, the question is to what extent provisions of labour law should interfere with the circumstances determined by the labour market. Concerning social rights, the level and means of the intervention by the state opens room for various theoretical approaches.

\section{The relationship between the market processes and the regulation of social rights}

In the process of studying impacts on the labour market, the analysis of constitutional issues seems a far-fetched approach ${ }^{2}$. Yet, I would like to point out here that a direct connection exists between the two, since firstly the obligations to act positively serve as guarantees on the labour market ${ }^{3}$, and secondly impermissible restraints under the rule of law are considered infringements on the functioning of the market. The success of political measures taken to improve macroeconomic conditions are also

\footnotetext{
Associate Professor, University of Debrecen Faculty of Law, Department of Agricultural, Environmental and Labour Law

${ }^{1}$ The paper is part of the K117009 „, The requirement of equal opportunity employment in he framework of HR tendencies reflecting changing expectations in labourlabour law" research project, National Research, Development and Innovation Office, contract registration number K117009.

${ }^{2}$ For constitutional evaluation of social rights in detail see H. Rab, The legal guarantess of sustainability of pension insurance provisions. HVG-ORAC Lap-és Könyvkiadó Kft., Budapest, 2012.

${ }^{3}$ See Vörös' poaition that in the case of right to social securtiy, the basic legal statur requires the state's action, positive engagement for the benefit of the indiviual, the state is obliged to inverne in the private sphere of the individual, as this constitutes the substance of its obligation. In: Vörös, I CC justice. 56/1995. (IX.15.) CCdecision, paralell opinion.
} 
inseparable from the level of constitutional protection ${ }^{4}$. The constitutional protection of social rights finds its shape in different political models 5 . One very distinct model is the liberal model found predominantly in Anglo-Saxon countries. The chief characteristic this model is that it links social provisions to demands in a way that is beneficial to the development of the market ${ }^{6}$. Thus, it can be even inferred that the potential impact of a basic right on the market is already considered during the definition process of that basic right. The facts that the constitutions of Anglo-Saxon countries, like the United States and the United Kingdom, make no direct reference to social stability and that social protection does not appear as part of the raison d'état can be viewed as the consideration of the interests of the market and the safeguarding of flexibility and adaptability in terms of social rights. At this point, however, it does not mean that there is unawareness for the rights to social security, but the detachment in legislation creates the room to directly consider the bearing capacities of the state that are present in constitutional regulations of other countries ${ }^{7}$ or defined in the Constitutional Court's jurisdiction in the case of Hungary.

\subsection{Anglo-Saxon approach}

As the demo nstration of the differences between the Anglo-Saxon and continental systems and their effect on the tendencies in the development of law was my starting point, I will elaborate on the Anglo-Saxon approach. In case of the US structure it is clear that despite the legislative detachment the concepts of economic and social rights are generally accepted. The American economic model - considered by many as the ideal model of economy and state - the notion of "minimum state, maximum market" prevails ${ }^{8}$. The propensity of the American model appears in Dahrendorf's opinion, who claims that Americans do not favour the concept of entitlement to social allowances, as it discredits the individual's demand to receive assistance from the local community ${ }^{9}$. Even today, welfare demands are not indispensable parts of economic reforms, which again supports my argument that the Anglo-Saxon legal mind fundamentally differs in terms of legislation and codification.

In the eyes of the majority of American lawyers the incorporation of economic and social rights into the constitution does not come into question, constitutional scholars argue that constitutional rights should be tried in the courts of law. It is generally accepted that only negative rights can be successfully tried in courts: those that stipulate a prohibition for the state ${ }^{10}$. contrary to this, in my view, there are negative

\footnotetext{
${ }^{4}$ Z. Fleck et.al., 2011. p. 69.

${ }^{5}$ Zs. Balogh, A szociális jogok érvényesülésének elméleti modelljei, különös tekintettel a szociális biztonsághoz való jogra. In: B. Molnár-Zs. Gyombolai - A. Téglási, Gazdasági alapjogok és az új magyar Alkotmány.Tanulmánykötet, Published by the Parliamentary Committee on Human Rights, Minorities, Cvili society and Religious Affaris., 2011.p. 70.

${ }^{6}$ A. Téglási, A szociális állam „erodálása” vagy megmentése? - avagy a szociális biztonság az új Alaptörvényben. Jogelméleti Szemle, 2011. Vol. 11. No. 4. p. 2.

${ }^{7}$ The Fundamental Law brought change to the Hungarian legal regulations as the principle of sustainable budgetary management was introduced in the Foundation section's Article) Paragraph (3).

${ }^{8}$ A. Simonovits, Egyenlőtlen társadalmak: Jövedelemeloszlás és a társadalmi szerződés. (Discussion of Roland Bénabou's paper) Esély, 2001. Vol. 12. No. 5. p. 115.

${ }^{9}$ This rests upon the American societal structure: immigrants had to rely on themselves and mentality was handed done to their descendants R. Darendorf, A modern társadalmi konfliktus. Gondolat Kiadó, Budapest, 1994. pp. 112-113.

${ }^{10}$ H. Schwartz, Van-e helyük a gazdasági és szociális jogoknak az alkotmányban? Fundamentum, 1998. Vol. 2. No. 3. p. 5.
} 
rights among social rights; accordingly the judiciary protection of these is also inevitable, thus the incorporation of these into the constitution cannot be ruled out. Still, some reluctance can be observed in the American jurisdiction, as several rulings declare the majority of social rights as public subjective rights at least ${ }^{11}$.

Constitutional thinking - that while first generation rights are negative rights, meaning that these constrain the state and thus create the fundamental features of these rights, and second generation rights are positive rights which require the state's active involvement, hence are not guarantees of entitlement but instruments that force the state to act - also appears in the Anglo-Saxon jurisprudence. In the Hungarian constitutional approach - which I also endorse - in the case of social rights, beyond the legal guarantees another level, material guarantees, also evolve. It must be underscored that the trust in the rule of law considerably depends on the proximity of legal and material guarantees ${ }^{12}$. It can be therefore argued that in the development to the system of guarantees, besides the constitutional protection, the role of the market also plays a significant role.

Positive rights are not unknown to American constitutional jurists but they do not hold it necessary to include them in the constitution. Many even claim that the quality of the constitution correlates with the brevity of its text ${ }^{13}$. Sunstein considers the concept positive rights to be equivalent to social rights, confining thereby the continental understanding of social rights ${ }^{14}$. Sunstein argues that "constitutions can be perceived as documents that are used to achieve very particular and practical goals, for instance to build a protective shield in advance against problems that will arise with highest probability in the political process" ${ }^{15}$. This certainly does not mean that constitutional requirements for social allowances do not exist in these countries, as the avenues are open to refer to other constitutional provisions, e.g. rule of law, equality before the law, in the case of the state's obligation to provide social benefits ${ }^{16}$.

\subsection{Continental approach}

In contrast to the position of American constitutional jurists, German basic law (Grundgesetz) represents the continental approach that is also dubbed as legal upholding regulation. The special feature of this system is that instead of the constitutional declaration of social rights, through the requirement to enact such laws the constitution renders the state's obligation to provide social benefits a raison d'état. This leaves the state great leeway for proper legislation that meets the constitutional requirements and constitutional provisions remain merely guarantees. In the Hungarian constitutional system the declaration of fundamental rights is also not sufficient, since particular legislation, the direct action of the state is necessary to

\footnotetext{
${ }^{11}$ Gy. Kiss, Alapjogok kolliziója a munkajogban. (Propositions) Pécs, 2006., p. 12.

${ }^{12}$ A. Téglási, 2011. 3. p., Vö.: Vörös Imre CC Justice 56/1995. (IX.15.) CCdecision, paralell opinion; Zs. Balogh, Az értelmezés hatalma - szociális jogok az Alkotmányban. Formatori Iuris Publici. Tribute to Professor Géza Kilényi 70th birthday. B. Hajas - B. Schanda (ed.), Szent István Társulat, Budapest, 2006., pp. 26-27.

${ }^{13}$ In the more than 200 years of the history of the Constitution of the United States, several amendments were based on this. Schwartz 1998., p. 8.

${ }^{14}$ R. C. Sunstein, A pozitív jogok ellen. Fundamentum, 1998. Vol. 2. No. 3. p. 11.

${ }^{15}$ Sunstein 1998. p. 11.

${ }^{16}$ G. Juhász, A gazdasági és szociális jogok újraszabályozásának szükségessége. Fundamentum, 2012. Vol. 16. No. 1. p. 45.; A. Téglási 2011. p. 3.
} 
realize these goals ${ }^{17}$. This, seen from an extremist viewpoint, questions the constitution itself and its significance in this regard, yet a more moderate stance also points to restrictions of constitutional rights.

A paramount ingredient of the rule of law is a constitution observing the international documents of fundamental human, civil and political rights that tallies the principles and fundamental rights, which directly set the framework and contents of legislation ${ }^{18}$. It is obvious that this requirement must apply not only to constitutional levels, but must be relevant through the entire system of law of individual countries. The potential materialistic limitations on guarantees square the recognition of market interests with the system of constitutional protection.

The chronological dimensions of economic, social and cultural rights also differ from those of the civil and political rights. In the case of civil and political rights, the obligation of the state directly occurs, while the realization of economic, social and cultural rights is incremental ${ }^{19}$. This gradual accomplishment, however, does not encompass the passivity of governments, the abandonment of providing social rights or the subordination of these in the long run, even without constitutional guarantees. The maximum level of the state's activity is guaranteed by the provisions and control mechanisms of international agreements. The state's consideration of the market interest is always limited by these. Yet, the latest international or EU-level legislation, for instance the $34^{\text {th }}$ Article of the European Union's Charter of Fundamental Rights, defines the issue of social security without creating a federal level of subjective law by acknowledging - though not guaranteeing - entitlements to social security provisions and allowances.

The protection of first generation political rights is inseparable from the sustainability of institutions of the market economy. Moral and business interests inevitably justify the resistance against the state's provocative intrusion into the private sphere ${ }^{20}$. In the EU level we find the conflicts of market interests and labour law's classical protection aims, for example in the famous Viking ${ }^{21}$ and Laval $^{22}$ cases of the ECJ and also in

${ }^{17}$ G. Halmai, Az alkotmányozás kockázatai. Jogtudományi Közlöny, 1997. Vol. 52. No. 3. p. 156.

${ }^{18}$ A. Ádám, Az emberi és állampolgári jogok jellegéröl és korlátairól. Jogtudományi Közlöny, 1993. Vol. 48. No. 11-12. p. 409-421.

${ }^{19}$ G. Kardos, A gazdasági, szociális és kulturális jogok néhány sajátossága - Egy megközelítés Magyar Tudomány, 2003. Vol. 48. (109.) No.10. p. 1282.

${ }^{20}$ Z. Fleck et.al., 2011. p. 69.

21 In the Case C-438/05 (The International Transport Workers' Federation and The Finnish Seamen's Union v. Viking Line ABP and OÜ Viking Line Eesti) we can find the same starting points from the ECJ as we summarized previously: "23. The provisions on establishment and the freedom to provide services are by no means irreconcilable with the protection of fundamental rights or with the attainment of the Community's social policy objectives. Neither the Treaty rules on freedom of movement, nor the right to associate and the right to strike are absolute. Moreover, nothing in the Treaty suggests that the Community's social policy objectives must always take precedence over the objective of having a properly functioning common market. On the contrary, the inclusion of both policy objectives in the Treaty signifies the aim of the Community to bring these policies together. Therefore, the fact that a restriction on freedom of movement arises out of the exercise of a fundamental right or of conduct falling within the ambit of the social policy provisions does not render the provisions on freedom of movement inapplicable."

22 In Case C-341/05 (Laval un Partneri Ltd. v. Svenska Byggnadsarbetareförbundet and Others) the ECJ positioned on the same way like Viking case: „3. Although the right to take collective action must be recognised as a fundamental right which forms an integral part of the general principles of 
Alemo Herron case $\mathrm{e}^{23}$. All of these case confirm the theory that in legal practice labour law depend on the market and in these cases the ECJ saved the freedom to conduct against labour law's aim (primary from collective labour rights).

\subsection{Hungarian viewpoint}

The expansion of the protection of fundamental rights to social rights is regarded as perilous by the constitutional trade journals primarily because it theoretically carries the risk that political rights might be curtailed for the sake of providing social rights, which might, as a negative impact, lead to the lowering of the level of protection of the classic fundamental rights ${ }^{24}$. Contrary to this, in the Hungarian literature, Juhász believes that for the protection of the private sector and the market, it is necessary to introduce a proper level of protection of social rights. Juhász points out that the obligation of the state to provide social benefits through the institutions of social security was omitted from the current Basic Law, and further the Basic Law envisages the provision of social security for those in need, thus this might roll back the social security benefits previously safeguarded as property and at the end of the day it could lead to the obfuscation of social security and being in need ${ }^{25}$. From this reservation it is clear that the inappropriate level of protection of social rights can lead to the erosion of property rights and consequently to the loss of guarantees in social rights, which opens the way for market jeopardizing state interventions. It is, however, in the interest of the state to protect property, since it affects the harmony and development of the society, the communities and the state itself. Through elaborating on this hypothesis Balogh in his paper argues in detail that just as fundamental rights are not the sum of scattered guarantees, but a unified set of values focusing on the protection of the individual's autonomy and personality, so society cannot be seen as an optional cluster of individuals, rather it is arguably a moral community. The greater latitude for implementing social rights increases the responsibility of a member of a society against another, but also reinforces the background security of those who

Community law the observance of which the Court ensures, the exercise of that right may none the less be subject to certain restrictions. As is reaffirmed by Article 28 of the Charter of Fundamental Rights of the European Union, it is to be protected in accordance with Community law and national law and practices.

Whilst the protection of fundamental rights is a legitimate interest which, in principle, justifies a restriction of the obligations imposed by Community law, even under a fundamental freedom guaranteed by the Treaty, the exercise of such rights does not fall outside the scope of the provisions of the Treaty and must be reconciled with the requirements relating to rights protected under the Treaty and in accordance with the principle of proportionality.

It follows that the fundamental nature of the right to take collective action is not such as to render Community law inapplicable to such action, taken against an undertaking established in another Member State which posts workers in the framework of the transnational provision of services.

(see paras 91, 93-95)"

23 In the case of Mark Alemo-Herron and Others v. Parkwood Leisure Ltd. (C-426/11) was the starting point: "25. However, Directive 77/187 does not aim solely to safeguard the interests of employees in the event of transfer of an undertaking, but seeks to ensure a fair balance between the interests of those employees, on the one hand, and those of the transferee, on the other. ... 36. Article 3 of Directive 2001/23, read in conjunction with Article 8 of that directive, cannot be interpreted as entitling the Member States to take measures which, while being more favourable to employees, are liable to adversely affect the very essence of the transferee's freedom to conduct a business (see, by analogy, Case C-544/10 Deutsches Weintor [2012] ECR, paragraphs 54 and 58).”

${ }^{24}$ With the extension that according to Balogh social rights cannot be views as a homogenous group. In: Zs. Balogh, in: B. Hajas - B. Schanda (ed.), 2006., p. 26-27.

${ }^{25}$ G. Juhász, 2012. p. 47. 
momentarily enjoy a more favourable status ${ }^{26}$. Following this path the link between social rights and the market becomes obvious. In terms of employment it unequivocally manifests itself on the labour market ${ }^{27}$.

Beyond the principles of fundamental law the other turf where the fundamental law approach is applicable in the field of employment, is the regulation of labour law. I will discuss this in the following.

\section{The level of labour law's intervention into social and employment affairs}

For a start, it should be pinned down that legislation is not the only manifestation of labour law in the framework of employment conditions, since in this context the agreement of parties has a significant role. As Kahn-Freund said: "Law is a technique for the regulation of social power." 28 Several forms of non-hard-law regulations - it may be termed soft-law - that are common in Anglo-Saxon legal environment, are also present in labour law. In general, in both Anglo-Saxon and continental legal systems, the self-regulating mechanisms of organizations, organizational customs, and organizational cultures serve as starting points. Furthermore, out-of-organization inputs and instruments of employment management developed in the face of competition, can also be considered.

\subsection{Economic rationality v. protective attitude}

This new role of labour law is closely related to the HR-management approach of economics that employees are deemed as human capital, which hence attaches economic rationality to the protective attitude of labour law. In economics, human capital was also dilated with a sort of moral, ethical dimension. The Nobel-laureate economist Amartya Sen is a principal representative of this approach. Sen claimed that economic growth cannot be exclusively gauged by material and economic benchmarks, but other aspects that are beyond the economic indicators should be included among the factors that determine development, i.e. the opportunities of economic players should be widened. A central element of this is the power of human capital, the freedom of the people to act, which should be considered as an economic factor in the market ${ }^{29}$. For the reinforcement of human capital the labour and social law instruments should be considered, since they make up for the legal environment that determines the room for the actors of the labour market. On the one hand, it establishes the scope of action for the employer, on the other it specifies the guarantees that lend the employees protection. This brings us back again to the argument that the balance between labour law and social rights ensures the stable labour market functions, thus it is advisable to stick to this balance as the law

\footnotetext{
${ }^{26}$ Zs. Balogh, B. Hajas - B. Schanda (ed.), 2006., p. 28.

${ }^{27}$ Vörös Imre puts the following question: Based on the model of the autonomous individual, who acts autonomously, supports himself by his own efforts and by the possessions achieved by this effort, who provides for himself based on his on discernment, decision and responsibility, the question can be raised: why cannot direct entitlements be established for the realization of social rights?" In: I. Vörös, A szociális biztonsághoz való jog az Alkotmánybíróság gyakorlatában. Világosság 2001. Vol. 42. No.1. p. 57.

28 O. Kahn-Freund, Kahn-Freud's Labour and the Law. (ed.: Paul Davies and Mark Freedland) Third Edition, Stevens and Sons, London, 1983. p. 14.

${ }^{29}$ S. Amartya, “Work and rights. ” ILO, International Labour Review, 2000., Vol. 139, No. 2., pp. 119 129.
} 
develops. Sen suggests the holistic approach to the questions of economic opportunities, political freedom, social provisions, the guarantees of transparency and living standards. The joint availability of these will encourage the individual to actively participate in change and not remain passive beneficiaries of allowances ${ }^{30}$. The guarantees of development thus become available.

\subsection{Market aspects}

Market aspects are included in the aspects of employment through non-labour law instruments. Firstly, this means the birth of various incentives, a sort of soft law selfregulating mechanism. Secondly, the demand for appropriate regulations of labour, predominately based on HR-management methods, and flexibility, i.e. the contractual freedom, also appear in labour law. These intentions compromise labour law and lower the level of social protection. The reflections to these issues belong to the field of law, particularly labour law, and not of economics, as the relationship between law and the economy constantly changes. In this respect, the objective is not the achievement of a static balance, the challenge for labour law is rather a construction of a regulative legal environment that serves development. Accordingly, the relationship between market and labour law becomes an outstanding field of research within the realms of labour law. Anglo-Saxon researchers are better positioned as the inflexibility of statutory law does not bind them. Yet, even by accepting this, the relationship of labour law and the market must be further investigated. Deakin examined the role of labour law in market growth, the inclusion of human capital's interests into labour law, in detail. In this way, he created clusters based on the impact of labour law on the market: market restricting, market amending and market creating functions ${ }^{31}$. The establishment of such relationships is possible by labour law and non-labour law instruments. However, it must be added that all self-regulating mechanisms can prevail in the mandatory set of laws, if there is demand for it. This process - along with the autonomous development track of labour law - should be acknowledged regardless of a theoretical point of start. Any agreement of the parties may be put into a contract, and in respect to a group of employees this intention can be formalized in a collective agreement, which is recognized by the law. A regulatory process started by the employer, the formulation of by-laws is acknowledged by Hungarian law as a valid form of labour law regulation ${ }^{32}$. To put it simple, the role of labour law elevates the questions of employment from the individual level to the general level of the community ${ }^{33}$. These general tendencies in labour law are based on the outcomes of the above mentioned quandaries and seek answers to the question: what is the role of labour law in the employment trends that focus on economic growth? This issue must be addressed in this paper, because this encompasses the problem of the level of legal protection in employment affairs. The significance of Sen's theory based on economy is stressed by the fact that it elevates human capital and economic growth to basic law level and attributes a value to them that must be

\footnotetext{
${ }^{30}$ S. Amartya, A fejlödés mint szabadság, Európa Könyvkiadó, Budapest, 2003., p. 11.

${ }^{31}$ S. Deakin, The Contribution of Labour Law to Economic and Human Development in: G. Davidov B. Langille (ed.) The Idea of Labour Law New York, Oxford Press, 2011., pp. 156-159.

${ }^{32}$ See the Act on Labour Law 2012/I. (Mt.) Article 17, that lists employer's internal policy among the legal declarations

${ }^{33}$ Hepple argues similarly: „Labour law stems from the idea of the subordination of the individual worker to the capitalist enterprise..." Quoted by: S. Deakin - G. S. Morris, Labour Law (5 ${ }^{\text {th }}$ edition). Hart Publishing, Oxford and Portland, Oregon, 2009, p. 1. See in original: B. Hepple (ed.), The Making of Labour Law in Europe. Mansell, London, 1986, Introduction, 11. p.
} 
protected. Langille, based on Sen's theory, views human capital as the moral foundation of labour law's development ${ }^{34}$.

\subsection{The focuspoint of the labour law}

Based on Deakin's cauterization, it must be examined whether labour law is a regulatory instrument of the economy or a legal guarantee that checks the processes. Arthurs explicitly argues that labour law's focus should shift to areas outside legal regulation $^{35}$, thereby implying that it is the duty of law to provide the framework of guarantees. Yet, even contrasting, more conservative, continental approaches and attitudes - like Weiss' position, who argues that direct legislation is necessary in terms of labour law's objectives and methods ${ }^{36}$ - acknowledge the need to refresh labour law in order to make regulatory instruments more efficient ${ }^{37}$. Thus, as a summary it can be stated that those supporting the classic hard law are not against the renewal of labour law, but insist on creating the legal framework for the processes of the labour market, particularly for the interest of the employees, who are on the weaker end of a tilted relationship.

The main question can be formulated this way also: does labour law play a direct regulatory role or should it only provide legal frameworks and guarantees for employment? In both cases, the guaranteeing position of labour law can be recognized, which can renew just as labour law itself can. Bellace revisited the assessments of the right to work from a human rights stance in light of the accords of international organizations and EU law, and pointed out that the interests of employers and employees are contrasting in this question ${ }^{38}$. It can therefore be deduced that the level of impact of the processes on the labour market repositions the regulatory role of labour law. The protection of employees justifies the notion that labour law should provide guarantees, not only framework. Moreover, it means the elevation of this, if the direct regulatory role of labour law is accepted. In contrast, in the position of the employers, who operate in an ever changing environment and are exposed to processes on the labour market, the recognition of fundamental rights is also dubious ${ }^{39}$, consequently they strive to reduce the regulatory role of labour law to a minimum.

The following issue can be derived directly from the previous question: should legislation accommodate the interests of the market, or should it follow a higher aim? The various positions of labour law are also split in this question. More conservative, continental scholars ${ }^{40}$ intend to cut labour law free from demands from the economy, as they see the undermining of labour law's significance in the too close

\footnotetext{
${ }^{34}$ B. Langille, Labour Law's Theory of Justice, in: G. Davidov - B. Langille (ed.) The Idea of Labour Law. Oxford University Press, New York, 2011. p. 112.

${ }^{35}$ H. W. Arthurs, Labour Law after Labour. Osgood CLPE Research Paper 2011. No. 5. pp. 12-29.

${ }^{36}$ M. Weiss, Re-Inventing Labour Law. In: G. Davidov- B. Langille (ed.) The Idea of Labour Law. Oxford University Press, New York, 2011. pp. 43-57.

${ }^{37}$ J. Howe, The Broad Idea of Labour Law. In: G. Davidov- B. Langille (ed.) The Idea of Labour Law. Oxford University Press, New York, 2011. pp. 299-300.

${ }^{38}$ J. Bellace, Who Defines the Meaning of Human Rights at Work? In: E. Ales - I. Senatori (ed.) The Transnational Dimension of Labour Relations. A new order in the Making? Collana Fondanzione Marco Biagi, G. Giappichelli Editore, Torino, 2013. pp. 111-135.

${ }^{39}$ Bellace cites employers' concern with regard to the right to srike. See: Bellace 2013. pp. 111-135.

${ }^{40}$ Például Rolf Birk and Prugberger Tamás.
} 
interdependence. Modernist researchers - who base their argument on Anglo-Saxon jurisprudence, which has a different approach to statutory law - straightforwardly recognize that the substance of labour law is defined by the market. Deakin argues that labour market processes and the outcome of changes substantially determine the closely related labour law $^{41}$. Further, others extend the range of labour law. Vosko argues that labour law covers the entire scope of labour market processes and is therefore not confined to the concept of employment ${ }^{42}$. Mitchell and Arup define labour law as law of the labour market ${ }^{43}$. This distinction appears in the selection of the level of regulation and in the recognition of the aforementioned soft laws as substitution for statutory law; however this approach is not widely accepted in trade journals.

In order to answer the previous question, other questions can be raised. Based on the assumption that in the absence of legislation, soft laws can integrate even HRmanagement tendencies into employment affairs, the question can reasonably be raised: Would it not be useful to open toward soft law regulations instead of legislation tailored to the interests of the market? This question, compared to the continental legal system, has a very different importance in the Anglo-Saxon legal system, where it is seen as a matter of decision, while in continental systems the issues of legal protection and trials also emerge simultaneously. The statutory law mind-set in continental law means that the issue of enforcement is also present in the thinking. Consequently, situations regulated by the law are deemed safer and mean a higher level of legal protection for legal entities in contrast to voluntary abiding and enforcement. From this point of view, regulation cannot shift totally in the direction of soft law, as it would endanger the existence of independent labour law. In our view, the soft law in continental law finds its role in the influence it exerts on the development of hard laws ${ }^{44}$. Or, as Fenwick and Novitz put it, the importance of modern regulatory instruments and methods lies in the fact that these innovatively reflect on the liabilities of traditional regulatory means. ${ }^{45}$

\section{Summary}

In summary it can be maintained that labour law and the system of social protection can be assessed with a holistic approach, which is not independent from economic development. In the case of social protection, the main goal is to increase safety from economic vulnerability and to establish guarantees for subsistence levels of living. In the development of labour law demands for more flexibility, the expansion of the decision-making autonomy of parties and the roll back in the level of legal regulation can be detected. At first sight, this appears as if they were opposing processes. Yet, this paper argues that this contradiction is not evident. The focus of the development in labour law is on the human capital, which - building on Sen's economic based theory - requires fundamental law protection, as it is the key to economic growth.

\footnotetext{
${ }^{41}$ S. Deakin - G. S. Morris 2009. p. 2.

${ }^{42}$ L. F. Vosko, Out of the shadow? In: G. Davidov- B. Langille (ed.) 2011. p. 368.

${ }^{43}$ Quoted by A. Kun, A munkajogi megfelelés ösztönzésének újszerü jogi eszközei. L’Harmattan, Budapest, 2014. p. 21.

${ }^{44}$ Further details are uncovered by Kun Attila. See: Kun 2014. Yet, these aspects fall out of the scope of this paper.

${ }^{45}$ Quoted by Kun 2014. p. 21. See orginial: C. Fenwick - T. Novitz, Conclusion: Regulation to Protect Workers' Human Rights. In: C. Fenwick - T. Novitz (ed.), Human Rights at Work. Hart Publishing, Oxford and Portland, Oregon, 2010. p. 605.
} 
Labour law must therefore create the protective guarantees of this human asset, also for the sake of encouraging economic development. This is in perfect harmony with the ambition of social rights that is to reduce the vulnerable position of employees by protecting their fundamental social labour and rights. In an ideal situation this dual demand - albeit from different points of view - leads to the same outcome from the aspect of the labour market.

There is nothing new under the sun, we need to balance - but with new tools - like we did it in the twentieth century. May not forget as Kahn-Freund said that "social welfare depends in the first place upon the productivity of labour, which in turn is to a very large extent the result of technical developments and it depends on second place on the force of the labour market, on which the law has only a slight influence." 46

\begin{abstract}
:
In the world of employment we can find several aspects that have effects on the labour market. Labour market cannot be independent from the legal regulation of employment; moreover - according to the tendencies - labour market processes basically define the role of labour law. A fundamental difference can be observed between the approach of Anglo-Saxon countries and researchers and the viewpoint of the continental law systems. In this paper the emphasized question is analyzed through these two different approaches according to the following premise: the Anglo-Saxon legal thinking defining the current development of labour law bears significant differences related to the labour law regulation - which means the direct regulation of the labour market - and to the legal guarantees behind employment as well. From the viewpoint of the labour market, two main questions are examined in this paper: on the one hand, the expected and necessary level and method of public intervention in connection with social rights, and on the other hand the depth of the intervention of labour law into the social relations driven by the market.
\end{abstract}

\title{
Keywords:
}

Social rights, labour market, tendencies of the labour law

\footnotetext{
${ }^{46}$ O. Kahn-Freund, Kahn-Freud's Labour and the Law. p. 13.
} 